\title{
Towards a Participatory, Co-operative and Sustainable Information Society?
}

\author{
A Critical Analysis of Swedish ICT Policy Discourses
}

\author{
Pieter Verdegem \& Christian Fuchs
}

\begin{abstract}
Sweden - like the other Nordic countries - is recognized as a leading IT nation. For this reason it is important to evaluate the specificities of Swedish policy discourses on the information society. The development of the information society has been a key topic in policy debates since the mid-1990s. More recently, new concepts such as 'sustainable' or 'green knowledge society' have emerged. This puts forward new questions about which type of information society we aim to achieve.

The present article contributes to the theoretical foundations of information society policies by introducing the notion of a participatory, co-operative, and sustainable information society (PCSIS). We apply this notion to Swedish policymaking by investigating ICT policy discourses. We also make a comparison with the recently launched Digital Agenda, the grand vision of the European Commission regarding the future of the information society.

Our overall conclusion is that Swedish and European visions can be labeled as dualistic and reductionist approaches, respectively. This means that both approaches fail to come up with a more elaborated perspective on the information society that links the key aspects participation, co-operation and sustainability in a convincing way. A dialectical approach, i.e. an approach that considers sustainability in multidimensional and interdependent aspects, is currently lacking in both Swedish and European policymaking.
\end{abstract}

Keywords: information society, participation, co-operation, sustainability, ICT policy discourses, Sweden

\section{Introduction}

'Sweden is a leading IT nation'. This statement is often found in texts describing the vision and ambitions of the Swedish ICT landscape, whether they are scholarly articles (Hall and Löfgren 2004, 156; Olsson 2006, 612), policy documents (Swedish Government 2000, 2011) or political speeches (Hatt 2010). But what does it mean to be a leading IT nation? And how should we evaluate this claim?

Recent official statistics (Eurostat 2011) illustrate the leading role of Sweden in Europe when it comes to the development of the information society. Based on a limited set of basic ICT indicators from 2010, we learn, first, that $88 \%$ of Swedish households had access to the Internet at home. Within the EU, only the Netherlands (91\%) and Luxembourg $(90 \%)$ had a higher Internet penetration. Second, $88 \%$ of Swedish citizens used the Internet 
at least once a week. This makes Sweden the absolute leader within the EU (together with the Netherlands, $88 \%$ ). And, third, $68 \%$ of Swedish citizens used the Internet for interacting with public authorities during the past 12 months. Sweden is one of the leaders in the EU, as only Denmark has a higher percentage (78\%) for the use of e-government services.

Given these figures, it is obvious that Sweden is one of the frontrunners in European ICT uptake and use. This makes a deeper analysis of Swedish information society policies particularly relevant. The major research question asked here is: What are the specificities of Swedish policy discourses about the information society? We first present a theoretical foundation for looking at information society policies - the participatory, co-operative, and sustainable information society (PCSIS) - and then apply this framework to the context of the Swedish information society. We investigate the extent to which Sweden - as a leading ICT nation - is also a frontrunner when it comes to the establishment of an information society that simultaneously strives towards participation, co-operation and sustainability. Given the attention currently paid to the European Digital Agenda - the European strategy for smart, sustainable and inclusive growth (European Commission 2010) - we also compare Swedish policy discourses with the position of the European Commission. This comparative analysis allows us to explore to what extent Swedish information society policies reflect dominant European patterns (which can more or less be described as a neoliberal policy perspective) or have diverged from them (e.g., by giving more attention to social concerns). We define the major patterns underlying Swedish ICT policies and explore the role of sustainability in these discourses. We then propose a reconceptualization of sustainability in the context of information society policies, especially through the connection of the notions participation, co-operation, and sustainability.

This article starts with a theoretical part about the foundations of the participatory, co-operative and sustainable information society. In the second section, we describe the methodological approach of our analysis. In the following sections, we reflect on both Swedish and European ICT policy discourses and compare them to each other. Finally, some concluding remarks are presented.

\section{Classifying Concepts of the Participatory, Co-operative, and Sustainable Information Society (PCSIS)}

Since the mid-1990s, the development of the information society has been a key topic in policy debates. More recently, we have observed the rise of concepts such as a sustainable information society or a green knowledge society (see, e.g., Forge et al. 2009). Sustainable and green have become buzzwords and have increasingly been employed in scholarly and political debates on what kind of society is desirable. Overall, these discourses signify a shift towards the view that not just any information society is needed, but an information society that is actively shaped by humans in a good way in order to gain desirable qualities. Within this shift, normative judgments have or will become more important. But these discourses are also fragmented and lack a theoretical foundation that attempts to provide concise definitions of the categories in use. A systematic theoretically grounded comparison of such categories is still lacking.

The distinction between base (economy, technology, nature) and superstructure (polity, culture) can be helpful for investigating and understanding modern society (Fuchs 
2008). Wolfgang Hofkirchner $(2002,2013)$ introduced, in this context, a typology of four worldviews that is based on the potential relationships between the base and superstructure of society. The typology distinguishes potential relationships between the two categories: (1) reductionism establishes identity by eliminating the difference to the benefit of the smaller, less differentiated part; (2) projectionism establishes identity by eliminating the difference to the benefit of the larger, more differentiated side; (3) dualism eliminates identity by establishing a difference of the two sides - it is a disjunctive approach - and (4) dialectical thinking integrates the two sides in such a way that they have different and identical aspects - they yield a unity in diversity.

Applying Hofkirchner's typology allows us to classify definitions of a participatory, co-operative, and sustainable information society (PCSIS) (for a detailed discussion, see Fuchs 2010; Fuchs 2014: chapter 5). The base is less differentiated than the superstructure because all superstructure phenomena have economic aspects, whereas not all economic phenomena have political and cultural aspects. Hence the superstructure is more differentiated and builds upon the base. Consequently, in any vision of the information society, the following approaches can be distinguished:

- Reductionist approaches reduce sustainability to the economic base, i.e. they see economic, technological or ecological aspects as the determining factors, the superstructure is deduced from the base;

- Projective approaches consider political or cultural aspects as the sole determining factors of sustainability; they give priority to the superstructure, and the base is derived from the superstructure;

- Dualistic approaches assert the existence of a variety of dimensions of sustainability, but they consider these dimensions to be independent;

- Dialectical thinking conceives of sustainability as multidimensional, on the one hand, and interdependent, on the other. The various dimensions are seen as having their own specific relative autonomies, but as being at the same time related in complex ways, mutually constituting and influencing one another. The dialectical approach stresses contradictions of substainability.

Interestingly, although the dialectical approach is not dominant (the dualistic approach is the predominant one), it is shared by a number of institutions and authors who have provided definitions of the sustainable information society. One such organization is the Heinrich Böll Foundation: 'Sustainability of knowledge and information means firstly containing the currently dominating trends towards commodification, which is aimed at short-range use and at creating an artificial scarcity of knowledge, although, as a good, it is essentially free: the agents of commodification are not primarily interested in the long-range securing of individual and social development or for freedom in the use of knowledge and information' (Heinrich Böll Foundation 2003b, 1). Another one is the United Nations Educational, Scientific and Cultural Organization (UNESCO): 'Struggling for development is not to ensure that a few get rich at the expense of the rest, or maintaining non-viable companies or institutions. (...) Globalization currently imposed the notion of the market on everything: education, health, communication services, cultural affairs, etc., and political powers can do nothing about this. (...)' (Ospina 2003, 38). These views stress a balancing of dimensions, which would require 
decreasing the predominant economic influence on society. They are dialectical instead of dualistic, projective, or reductionist.

If we conceive of sustainability as a complex phenomenon, then it must include various aspects that need to be achieved in sustainable social systems, such as individual well-being, security, freedom, and self-determination as well as collective dimensions such as ecological preservation, wealth for all, social security for all, political participation for all, or health and education for all.

The correspondence of individual, organizational and societal goals could also be interpreted as a contemporary form of Kant's Categorical Imperative: 'Act only according to that maxim by which you can at the same time will that it should become a universal law. (...) Act as though the maxim of your action were by your will to become a universal law of nature. (...) Act so that you treat humanity, whether in your own person or in that of another, always as an end and never as a means only' (Kant 1998, 422, 429). Treating others with the same logic one wants to have applied to oneself means that there can be no morally privileged logic at any level. But Kant's Golden Rule fails in situations where people are willing to suffer, tolerate violence against themselves, or die if they were in the positions of others. Hence one assumption that may need to be added is that the logics employed at the individual, organizational and societal level should be guided by the spirit of co-operation and participation. This implies that the logic of co-operation is superior to the logic of competition. The Kantian categorical imperative needs to be further developed into the Marxian categorical imperative to 'overthrow all relations in which man is a debased, enslaved, abandoned, despicable essence' (Marx 1844/1975, 182 ), i.e. the judgment that a participatory co-operative society is needed.

Important in this discussion is how we can define the concepts participation, cooperation and sustainability (especially in relation to the information society), and in what way they are multidimensional and interdependent. Participation means that humans are enabled by technologies, resources, organizations, and skills to design and manage their social systems all by themselves, and to develop collective visions of a better future in such a way that the design of social systems can make use of their collective intelligence (Fuchs 2008). A participatory social system is therefore a system in which power is distributed in a rather symmetrical way. This means that humans are enabled to control and acquire resources such as property, technologies, social relationships, knowledge, and skills that help them in entering communication and co-operation processes in which decisions are taken on issues of collective concern.

Co-operation stands in opposition to competition, which means that certain individuals and groups benefit at the expense of others, i.e. there is unequal access to structures of social systems. Co-operation is a specific type of communication in which actors achieve a shared understanding of social phenomena, make concerted use of resources in such a way that new systemic qualities emerge, engage in mutual learning, and in which all actors benefit and feel at home and comfortable in the social system that they jointly construct (Fuchs 2008). Co-operation includes people interacting within a social system; it lets them participate in decisions and establishes a more just distribution of and access to resources. Hence, co-operation is a way of achieving and realizing basic human needs.

If we conceive sustainability as a complex phenomenon, then it must include various aspects that need to be achieved in sustainable social systems, such as individual wellbeing, security, freedom, and self-determination as well as collective dimensions such 
as ecological preservation, wealth for all, social security for all, political participation for all, or health and education for all (Fuchs 2010).

But how are participation, co-operation, and sustainability connected? Participation is structure-oriented; it is a process in which social structures are designed in such a way that individuals are included in the constitution of the social systems they live in and actually take part in these constitution processes. Co-operation is an inter-subjective process within a participatory structure; participation is a logical and necessary, but not sufficient, precondition for co-operation. Co-operation is the social process by which sustainable systems can be produced. Sustainability concerns the long-term form and effects of a social system. Participation means the structural enablement, co-operation the inter-subjective social process, sustainability the long-term condition and effects of social systems, in which all benefit and have a good life. Abstractly stated, a participatory, co-operative, and sustainable society is a society that guarantees a good life for all. A participatory, co-operative and sustainable information society (PCSIS) is a society in which knowledge and technology, together with social systems, are shaped in such a way that humans are included in and self-determine their social systems collectively, interact in mutually beneficial ways, and by so doing bring about a long-term stability that benefits all present and future generations and social groups. Such a society must necessarily be non-capitalistic and non-dominative (Fuchs 2010).

\section{The Methodological Approach}

In order to analyse policy discourses on the information society, we conducted a discourse analysis of material originating from the Swedish government. Discourse analysis can have a very broad scope. Jupp (2006, 279-280) presents a framework for critical document analysis in which the researcher asks a series of questions when analysing documents critically. These questions include: 'What does a critical reading of these documents uncover in terms of: [...] what is defined as 'right' and 'wrong' and therefore what is seen as problematic? [...] What does a critical reading of these documents tell us about (a) what is seen as problematic? (b) which explanations are rejected or omitted; (c) which solutions are preferred? [...] What alternative discourses exist? [...] What is the relationship between the discourses and social conflict, social struggle, hierarchies of credibility, order and control and, most of all, the exercise of power?' (Jupp 2006, 279f).

For the purpose of our study, we reformulated these questions to the context of the critical analysis of information society policies. We asked the following questions when analysing the selected documents: What kind of ICT policy vision is considered as right by the documents? To what extent is the logic of commodification and capitalism seen as problematic or accepted? To what extent is a problematization of neoliberalism and commodity logic omitted? What are the preferred policy perspectives presented? How do they relate to the exercise of power, especially economic power and the ideological power of neoliberalism? What alternative discourses for neoliberal ICT policies exist? Are they reflected in policy documents or ignored?

Our method is thus focused on a critical reading of policy documents. More specifically, we wish to uncover normative aspects (e.g., is the neoliberal logic of privileging in the last instance the capitalist logic over other logics seen as right or wrong, accepted or rejected? Ignored or discussed? Are alternatives considered or ignored?) in ICT policy 
documents and investigate the relationship between ICT discourses and the exercise of power. Our corpus consists of a diverse range of texts, including official government publications, political speeches, and vision reports. We begin our analysis with Swedish ICT policy discourses, but we have extended the corpus with material originating from the European Community in order to compare Swedish and European positions.

We have chosen an approach within discourse analysis that is simultaneously 'exploratory' and 'critical'. The exploratory character refers to the selection of the material that forms the subject of our investigation. We have used a longitudinal range of policy documents that stand as milestones in the development of Swedish policy discourses on the information society. The advantage of this historical approach is that it enables us to define the major patterns in Swedish ICT policies as they have developed over time. The earliest document in our corpus is the first official Swedish policy vision, published in 1994 by the government's IT Commission ('Information Technology Wings to Human Ability'), and the latest one a 2011 policy proposal for a Swedish Digital Agenda. Rather than scrutinizing the specific details of each policy document, we have chosen to outline the major patterns of the ICT policy discourses as they have developed over time.

The critical character of our approach refers to our attention to sociopolitical aspects of language use, discourse and power, as explained by the Frankfurt School and Critical Discourse Analysis (CDA) approaches. The Frankfurt School stipulates that social theory should aim at critically reflecting on the changes in a society instead of merely aiming at understanding and explaining that society. From this perspective, critical theory wants to produce and convey knowledge that promotes enlightenment and emancipation (Horkheimer and Adorno 1944/2002). It should enable human beings to emancipate themselves from forms of domination through self-reflection. CDA primarily focuses on demystifying ideologies and power through the investigation of data. The common ground of CDA is discourse, critique, power, and ideology (van Dijk 2011; Wodak and Meyer 2009). CDA scholars emphasize particularly the functioning of ideologies in everyday life. As Fairclough $(2003,218)$ states: 'Ideologies are representations of aspects of the world, which contribute to establishing and maintaining relations of power, domination and exploitation. They may be inacted in ways of interaction and incalculated in ways of being identities'. For Fairclough (2003), the analysis of texts is crucial because they are an important aspect of ideological analysis and critique. Studying the relation between language and power is important because power is central to understanding the dynamics and specificities of control (and action) in modern societies.

One important question is how to define ideology. Ideology is a process in which dominative groups address dominated groups and individuals, at which expense they maintain privileges and control of resources, using a system of ideas that tries to justify the existing conditions and forestall change (for an overview, see Žižek 1994). Eagleton (1991) has noted six core understandings of the concept of ideology: (1) the general material process of production of ideas, beliefs and values in social life; (2) ideas coherently symbolize the conditions and life experiences of a specific group or class; (3) the promotion and legitimization of the interests of a group or class in the face of opposing interests; (4) the promotion and legitimization of the interests of a dominant social group in order to unify a social formation; (5) ideas and beliefs that help to legitimate the interests of a ruling group/class through distortion and dissimulation; and (6) false and 
deceptive beliefs arising from the material structure of society as a whole. We employ an understanding of ideology that is close to the ideology definitions 4-6. This understanding has mainly been employed in the Frankfurt School tradition, whereas other thinkers like Mannheim, Gramsci, Althusser and Hall have developed general ideology theories. We consider the Frankfurt School ideology concept that is grounded in Marx's (1867) concept of fetishism and Lukács' (1923/1972) notion of reification to be more appropriate, because it allows us to criticize ideas that support domination and exploitation, whereas ideology theories have problems distinguishing between what ideas are normatively desirable and undesirable and face the problem of moral relativism.

\section{Analysis of Swedish and European Policy Documents}

\section{The Discourse of 'Early'Swedish Information Society Policy}

An important and overall goal of Swedish policies for electronic communication, IT and postal services is that everyone shall have access to a socially and economically effective infrastructure and associated social services with long-term sustainability (Bradley 2006, 219). Sweden's first official policy vision on the information society dates back to the mid-1990s (Henten and Kristensen 2000, 89). The governmental IT Commission launched a report entitled 'Information Technology - Wings to Human Ability' (1994). The IT Commission's task was to contribute to the benefits of information technology in Sweden in order to improve quality of life for the population and to increase the country's international competitive standing. Later, in 1998, another plan was launched entitled 'Changing Times, Changing Conditions'. This plan was one of the Swedish government's first elaborated visions on the information society. It addressed three major focus areas by asking the following questions: (1) How can IT use contribute to growth and employment? (2) How can IT availability be increased in society? (3) What is the scenario for the future, or in other words, what will be the consequences of IT use and which strategic decisions must be made? This report describes in particular how a new society - the knowledge society - is dawning. Hall and Löfgren $(2004,154)$ analysed this document and came to the conclusion that the basic underpinning idea embedded in the Swedish ICT policy discourse is that the knowledge society is not shaped by human actors, but rather by intangible forces. According to this discourse, forces such as IT develop a new type of society and humans should therefore comply with the technological development. Early Swedish IT visions thus contain both utopian and dystopian elements, but they all agree in one respect, i.e. that individuals will have to alter their ways of living and to adjust to the new era's requirements. We argue that early Swedish policy visions on the information society (Hall and Löfgren 2004) contrast with the perspective of a participatory and co-operative information society, because in a democracy it is important that citizens be actively engaged in developing society, rather than technology being the driving force.

In the year 2000, the Swedish government launched a vision for a nationally integrated and rejuvenated society, the so-called 'ICT Bill - an Information Society for All' [Ett informationssamhälle för alla] (Swedish Government 2000). This government bill - put forward by the then social democratic government - presented a two-tier strategy, in which both economic/expansive and democratic/inclusive factors were integrated. On the one hand, the discourse referred to strengthening Sweden's economic position 
in the global economy, which contained an economic, but also a nationalistic dimension (Hall and Löfgren 2004, 156). On the other hand, the Swedish government saw a great potential in the Internet and ICT-enabled applications for strengthening democratic citizenship, i.e. public control (of government) as well as dialogue, participatory democracy, and civic control (see Olsson et al. 2003). It was stressed that the purpose of creating an information society for all should be realized by primarily focusing on three areas: (1) confidence in IT (greater security and confidence); (2) competence in IT applications (greater know how, basic ICT skills for all citizens); and (3) access of citizens to the services of the information society (greater access to IT). Furthermore, the policy document stressed general goals such as growth, employment, regional development, democracy and equity, quality of life, gender equality, cultural diversity, efficient public administration, and a sustainable society. The latter aspect referred to using ICTs to promote ecologically sustainable development, thus helping to reduce the impact of, e.g., transportation and making IT equipment part of a sustainable, cyclic flow of materials.

In 2004, the Swedish government launched a new government bill entitled 'From an IT Policy for Society to a Policy for the Information Society' (for a discussion, see: Bradley 2006, 226). The main goal of this bill was to establish a vision of a sustainable information society for all. The argument was that politics increasingly should move from being concerned with IT infrastructure as such to focusing on the use of the technology by citizens and in companies/organizations. According to the text, specific attention should be paid to strengthening the position of so-called weak groups (the elderly, the unemployed, and immigrants) in order to prevent and reduce gaps in society. An important difference (especially in comparison to the bill of 2000) was that the notion of sustainability was featured more prominently. In this document, the Swedish government acknowledged that IT should equally contribute to economic, social, and environmental aspects. The main goals regarding how to achieve this were summarized by introducing three key aspects: (1) IT should contribute to improving quality of life and to improving and simplifying everyday life for humans and companies; (2) IT should be used to contribute to sustainable growth; and (3) an effective and secure IT infrastructure with a high level of transmission capacity should be available throughout the country, for example to provide humans with interactive public e-services.

Based on the typology of Hofkirchner (2002), one can evaluate the first Swedish policy visions (Information Technology - Wings to Human Ability, 1994 and Changing Times, Changing Conditions, 1998) as examples of a reductionist approach: technological changes are seen as the sole drivers of the development towards a knowledge society and citizens should be empowered by providing themselves with resources and capacities that enable activity in decision-making processes. The policy focus in these documents is rather purely on growth of the ICT industry, whereas non-economic goals such as strengthening welfare, democracy, and ecological sustainability are ignored. Such a reductionist approach often goes together with a neoliberal perspective on society. Within neoliberal political and economic visions, the focus is (almost) exclusively on economic growth (growth and employment) and capital accumulation: 'Neoliberalism is in the first instance a theory of political economic practices that proposes that human well-being can be best advanced by liberating individual entrepreneurial freedoms and skills within an institutional framework characterized by strong private rights, free mar- 
kets and free trade. [...] It holds that the social good will be maximized by maximizing the reach and frequency of market transactions, and it seeks to bring all human action into the domain of the market. This requires technologies of information creation and capacities to accumulate, store, transfer, analyze, and use massive databases to guide decisions in the global marketplace' (Harvey 2005a, 2-3).

When comparing more recent Swedish policy visions (ICT Bill - An Information Society for All, 2000; From an IT policy for Society to a Policy for the Information Society, 2004) with the earlier versions, one can conclude that there is a notable shift from a reductionist approach to a dualistic vision. Indeed, this later vision strived to strengthen the Swedish position in the (ICT-based) economy while it simultaneously formulated opportunities for fostering democracy and inclusion of all citizens (information society for all). Dualistic approaches define multiple goals and dimensions of the information society, but do not consider whether these goals are compatible or contradictory and whether and how they are causally linked (Fuchs 2010, 32-36). The 2000 and 2004 ICT policy visions formulated non-economic goals such as democracy, quality of life, gender equality, ecological sustainability, but at the same time they were intended to advance capital accumulation, especially in the IT industry. Such dualistic arguments are idealistic and naive because they are detached from the reality of capitalism. More specifically, it is doubtful whether this perspective of a sustainable information society indeed leads to improving the quality of life of all citizens or whether it does not rather primarily lead to large benefits among members of one class. In Sweden, like in many other countries, the rise of neoliberal policies has resulted in an increase in inequality during the past decade (see Table 1). The information society discourse has promised a better society in all realms thanks to the rise of ICTs. The reality, however, seems to be that the neoliberal logic of the commodification of everything, privatization and financialization of common goods, and liberalization of markets has affected large parts of society (the communication commons including ICTs, telecommunications and media just like health, care, education, transport and infrastructure, the pension system, etc.), which as an overall combined effect has made Sweden, Europe, and the world more unequal.

Table 1. Social Development Indicators for Sweden (1999-2009) (Eurostat online)

\begin{tabular}{lccccc} 
& 1999 & 2002 & 2004 & 2006 & 2009 \\
\hline Income quintile ratio (80/20) & 3.1 & 3.3 & 3.3 & 3.6 & 3.7 \\
GINI coefficient & 22 & 23 & 23 & 24 & 24.8 \\
$\begin{array}{l}\text { At-risk of poverty rates (60\% of } \\
\text { the median equivalized income) }\end{array}$ & $8 \%$ & $11 \%$ & $11.3 \%$ & $12.3 \%$ & $13.3 \%$ \\
\hline
\end{tabular}

Some studies have critically evaluated the European agenda on the information society (eEurope and i2010) and have concluded that, despite the satisfaction shown in official appraisals, the conclusions that can be drawn from the reality of the European information society cannot be so optimistic (see, e.g., Gomez-Barroso et al. 2008). Similar criticisms of Swedish information society policies have been formulated earlier by, e.g., Olsson et al. (2003), who question whether the chosen path is the right one for Sweden. 


\section{A Digital Agenda for Europe and Sweden}

Building on Swedish policy visions on the information society, the Swedish EU presidency (2009) formulated a vision text about a Green Knowledge Society (Forge et al. 2009). This policy document was brought forward for preparing a new European vision of the information society. The document outlined three main themes: (1) attention to the social impact of ICT; (2) the need for economic prosperity in terms of jobs, revenues and national budgets; and (3) addressing climate change in meaningful ways (referred to as a 'Green New Deal') (Forge et al. 2009, 6). By doing so, the visions text proposed ten policy areas that should form an overall ICT policy framework for the EU for the next five to ten years: (1) the knowledge economy: driver of future wealth; (2) the knowledge society: participation for all; (3) green ICT: support for an eco-efficient economy; (4) next generation infrastructure: balancing investment with competition; (5) soft infrastructure: investing in social capital; (6) SMEs and ICT: supporting Europe's small enterprises; (7) a single information market: enabling cohesion and growth; (8) revolutionizing e-government: rethinking delivery of public services; (9) online trust: a safe and secure digital world; and (10) clear leadership: rethinking the EU's policy making process. The vision of a Green Knowledge Society (as it is presented in the report) thus strives towards integrating economic, societal and environmental aspects. It is an attempt to unite both Swedish and European visions/perspectives on the information society. This text was not an official EU policy vision as such, but aimed at providing inspiration for a new action plan that should come in place of the i2010 initiative that ended in 2009.

In 2010, the official new EU vision on the information society was launched. This plan is called the European Digital Agenda - Europe 2020. A Strategy for Smart, Sustainable and Inclusive Growth (European Commission 2010). It replaces its predecessors, such as the eEurope and 2010 initiatives. The overall aim of the Digital Agenda is 'to deliver sustainable economic and social benefits from a digital single market based on fast and ultra fast Internet and interoperable applications' (European Commission 2010,3). The economic orientation (see also the focus on the market in the statement above) is stressed, as this vision is meant to be the answer to the economic crisis: 'The Digital Agenda makes proposals for actions that need to be taken urgently to get Europe on track for smart, sustainable and inclusive growth' (ibid.). The EU's current technology and social policy framework mainly promotes competitiveness, innovation, and enterprise. Therefore, Bob Jessop (2008) describes the EU as a Schumpeterian workfare post-national regime, in which the state engages 'in the pursue of technological rents on behalf of capital', which results in 'the subordination of the totality of socio- economic fields to the accumulation process so that economic functions come to occupy the dominant place within the state' (Jessop, 2008, 132). By framing sustainability in terms of sustainable growth, the Digital Agenda subscribes to neoliberalism. Indeed, the focus is almost exclusively on economic growth (and capital accumulation), which is a common characteristic of a neoliberal viewpoint of society. 'The fundamental mission of the neoliberal state is to create 'a good business climate' and therefore to optimize conditions for capital accumulation no matter what the consequences are for employment or social well-being' (Harvey 2005b, 19).

In order to achieve the goal of economic growth (to which all other goals are subordinated), the Digital Agenda proposes seven action areas: (1) a vibrant digital single 
market; (2) promoting interoperability and standards; (3) promoting trust and security; (4) realizing fast and ultra fast internet access; (5) stimulating research and innovation; (6) enhancing digital literacy, skills and inclusion; and (7) striving towards ICT-enabled benefits for the EU society. Confronting these areas with the presented notion of a participatory, co-operative, and sustainable information society (PCSIS), we can conclude that there is limited or even no room for participation, co-operation, and a dialectical concept of sustainability. In the Digital Agenda, even (at first sight) non-economic areas, e.g. the area concerned with enhancing digital literacy, skills and inclusion, are part of a strategy that mainly supports achieving better performance in the economy. The following statement illustrates this circumstance: 'It is essential to educate European citizens to use ICT and digital media. [...] The supply of ICT practitioner and e-business skills, i.e. the digital skills necessary for innovation and growth, needs to be increased and upgraded' (European Commission 2010, 25). Inclusion and empowerment through literacy and skills are not considered to be moral values as such, but only values that are subordinated to economic value because they should contribute to innovation and growth. Goals that, in the first instance, are non-economic in nature are reduced to the topic of economic growth, which is a reductionist argument and, again, an indication of a neoliberal spirit (Fuchs 2010, 29-32). Jessop, in his work Future of the Capitalist State, refers to such a neoliberal policy perspective as the rise of the competition state: 'One major discursive-strategic shift in this regard is the demotion of 'productivity' and 'planning' in favor of an emphasis on 'flexibility' and 'entrepreneurialism'. Another is the shift from a discourse about entitlements and lifetime employment to one about obligations to engage in lifelong learning to ensure that workers are employable and flexible' (Jessop 2002, 133). In addition, the Digital Agenda uses sustainability only as a fashionable label for the type of economic growth that should be achieved. The $E U$ Digital Agenda thus recognizes sustainability only as an economic concept, while the Swedish proposition about a Green Knowledge Society (Forge et al 2009) also takes into account ecological aspects.

At the end of 2010, the Swedish minister responsible for IT, Anna-Karin Hatt, announced coming up with a proposal for a Swedish Digital Agenda (Hatt 2010). According to her, the Swedish government should continue to take a leading role in further developing the digital society. For this Swedish Digital Agenda, Mrs. Hatt has outlined five core areas: (1) the use of IT in health and medical care services; (2) the development of a truly accessible e-government system; (3) IT and how it can help in creating jobs, businesses and entrepreneurship in Sweden; (4) IT and the mission to reduce the ecological footprint; and (5) the question of how to enable more people to participate in the digital society. One year later, in December 2011, the Swedish Government published the policy document entitled 'ICT for Everyone. A Digital Agenda for Sweden' (Swedish Government 2011). This policy vision is the implementation of Mrs. Hatt's original plan to come up with a proposal for a Swedish Digital Agenda. An important characteristic of the plan A Digital Agenda for Sweden is the ambition for Sweden to ensure its world-leading position. 'The digital agenda is a tool for coordinating the Government's efforts and actions in the area of ICT. It is a way of kicking off a process that will lead to Sweden becoming the best in the world at exploiting the opportunities offered by digitization' (Swedish Government 2011, 15). Just as in other Swedish policy documents, this nationalistic dimension is omnipresent. In order to achieve this ambition, 
four strategic areas are distinguished: (1) easy and safe to use; (2) services that create benefit; (3) the need for infrastructure; and (4) the role of ICT in societal development.

For each of these four areas strategic challenges, initiatives are adopted and actions are presented. Although the plan A Digital Agenda for Sweden is betting on stimulating growth and productivity, societal challenges are not neglected: 'ICT does not just contribute to economic growth but also to improving and simplifying everyday life for everyone' (Swedish Government 2011, 12). This is reflected in how the strategic challenges for the main target areas are put forward. The section 'The role of ICT in societal development' contains information on the vision of how to integrate broader societal and environmental aspects. Specific attention is paid to topics such as research and innovation, ICT for the environment (i.e., the ecological dimension), gender equality, freedom on the Net (i.e., ensuring that human rights are respected on the Internet), copyright, and ICT for global development.

When comparing the Swedish Digital Agenda and the European Digital Agenda, one can conclude that the Swedish Government has a slightly different position than the EU does. At the same time, the most recent Swedish policy discourse is very much characterized by aspects that were already of great importance in earlier Swedish policy visions on the information society: Sweden should take a leading role in ICT development and adoption, but there should be simultaneous attention to economic, social, and environmental aspects.

The discussion of the different policy visions allows an evaluation and comparison of the Swedish and EU positions regarding the information society. Based on the analysis of the EU Digital Agenda, we can conclude that the EU position can be labeled as a reductionist approach. In this way it does not differ from previous plans such as eEurope and i2010 (see Fuchs 2010). The economic dimension is dominant and omnipresent at the expense of other aspects such as participation, co-operation, and (non-economic) sustainability. The two Swedish approaches (the EU presidency report and the vision of the Swedish Digital Agenda) are dualistic approaches because in these documents multiple goals and dimensions of a participatory, co-operative, and sustainable information society are postulated. These visions, however, do not consider whether the presented goals are compatible, whether they are contradictory and whether and how they are causally linked. A more general conclusion about Swedish ICT policies is that there has been a shift from a reductionist approach (the first policy texts on the information society, 1994 and 1998) towards a dualistic approach (more recent visions texts since 2000 and beyond).

Another conclusion is that Swedish policy discourses (like those in other Nordic countries) focus more on social concerns than do the larger EU framework policy documents and thereby are intended to influence EU policy (Henten and Kristensen 2000). At the same time, thus far Sweden has also failed to come up with an established vision of a sustainable information society, i.e. a vision in which participation, co-operation and sustainability are truly connected and not contradicted by a strong focus on neoliberalism. A dialectical approach - i.e. an approach that an approach that understands sustainability both in mulitdimensional and interdependent terms, and establishes an alternative to neoliberal information societies - is currently lacking in both Swedish and EU policymaking on the information society. 


\section{Conclusion: Towards a Dialectical Reality of Participation, Co-operation and Sustainability in the Information Society}

This article adds to the theoretical foundations of information society policies. In this context, the notion of a participatory, co-operative, and sustainable information society (PCSIS) was introduced. At the same time, a typology of four worldviews that is based on the potential relationships between base and superstructure was used to frame the discourse of both Swedish and European information society policymaking.

The reason why we question reductionist, projective, and dualistic approaches is that there is evidence that late-modern society is characterized by a culminating antagonism between economic growth and social and ecological cohesion and an antagonism between economic freedom (of markets) and social equity. Income inequality measured as the relation of the mean income of the upper and the lower quintile decreased during the period 1995-2000 in the EU countries, but it increased from 4.5 in 2000 to 4.9 in 2009 (Eurostat Online). The higher this measure, the higher the income disparity between the poorest and the richest. The at-risk-of-poverty rate after social transfers measured by $60 \%$ of median equivalized income after social transfers has risen from $15 \%$ in 1998 to more than $16 \%$ in 2005 in the EU countries (Eurostat Online). The increase in income inequality, job insecurity, and poverty risk has been accompanied by a polarization between capital and labour. Whereas the average profit rate (net returns on capital stock) has increased in the EU countries, the wage share (compensation per employee as percentage of GDP) has decreased (European Commission Annual Macro-Economic Database). It is reasonable to assume that, during the past couple of decades, economic growth has been accompanied by a rise in relative wage decreases, income inequalities, and poverty risks. Hence we assume that such a form of economic growth, i.e. the unhindered expansion of capital accumulation, is not compatible with social sustainability. The conclusion of many contemporary social scientists is that the dominance of economic logic needs to be driven back in order to achieve sustainability (see e.g. Calhoun \& Derlugian 2011a/b/c, Archer 2007, Harvey 2005, Stiglitz 2003) and that systemic alternatives are needed. It can therefore be hypothesized that economic sustainability, in the sense of the continued expansion of capitalist accumulation, is not compatible with social sustainability and that a paradigm shift is needed. Persistent economic growth has been achieved by compromising social sustainability (e.g., by reducing the total wage labour costs and advancing precarious jobs in order to raise profits) and by externalizing economic costs to nature. It has been based on the principle of accumulation by dispossession (Harvey 2005a). Less profitability and more corporate taxation are needed to provide the financial means that can be invested in social and ecological sustainability. Economic sustainability hence should not be understood as meaning continuously rising profit rates, but should better be conceived of as self-managed ownership, distributive justice, and the advancement of public goods (based on the insight that the commons are produced co-operatively and hence should be owned collectively).

Sustainability should be re-evaluated, and we especially need a multidimensional perspective on sustainability. Different dimensions of sustainability are presented in Table 2.

The dimensions of sustainability do not exist independently, but are interdependent. This means that the lack of a certain dimension eventually will have negative influences on other dimensions, whereas enrichment of one dimension will provide a positive po- 
Table 2. True Dimensions of Sustainability

\begin{tabular}{ll} 
Dimension & Definition \\
\hline Ecology: Preservation & Under the condition of ecological preservation, nature is treat- \\
ed by humans in ways that allow flourishing of natural sys- \\
tems, i.e. the autopoiesis of living systems is maintained and \\
not artificially interrupted or destroyed and natural resources \\
are preserved and not depleted.
\end{tabular}

Technology: Human-Centredness That technology is human-centred means that technological systems should help humans in solving problems, fit their capabilities, practices and self-defined needs, support human activities and co-operation, and involve users in definition, development, and application processes.

Economy: Equity Economic equity means that there is wealth for all, i.e. defined material living standards should be guaranteed for all as a right, nobody should live in poverty, and the overall wealth should be distributed in a fair way so to avoid large wealth and income gaps between the most and the least wealthy.

Polity: Freedom In line with the critical-realist thinking of Roy Bhaskar (1993), freedom can be conceived of as the absenting of domination, i.e. the asymmetrical distribution of power, so that humans are included and involved in defining, setting, and controlling the conditions of their lives. It is the absenting of constraints on the maximum development and realization of human faculties. Freedom then means the maximum use and development of what C.B. MacPherson (1973) has termed human developmental power.

Culture: Wisdom

A culture is wise if it allows the universal sharing and cooperative constitution of knowledge, ideas, values, norms, and sets standards that allow literacy and the attainment of educational skills for all, physical and mental health of all, the maximization of a life time in health for all, communicative dialogue in which all voices are heard and influential, a culture of understanding that allows finding common values without compromising difference (unity in diversity), the experience of entertainment, beauty, the diversity of places, mental challenge and diversity, physical exercise for all, and building communities, relations, love, and friendships for all.

tential for the enrichment of other dimensions. For instance, people who live in poverty are likely to have little time for political participation. Another example is that an unsustainable ecosystem advances an unsustainable society and vice versa. If we humans pollute the natural environment and deplete non-renewable natural resources - i.e. if we create an unhealthy environment - problems such as poverty, war, totalitarianism, extremism, violence, crime, etc. are more likely to occur. And the reverse also holds, that is, a society that is shaken by poverty, war, lack of democracy and plurality, etc., is more likely to pollute and deplete nature. Thus, sustainability should be conceived of as being based on the dialectic of ecological preservation, human-centred technology, economic equity, political freedom, and cultural wisdom.

Elements of an alternative approach to participatory, co-operative, sustainable information society (PCSIS) have thus far been marginalized in the information society policy discourse by the dominance of dualistic and reductionist approaches. None- 
theless, there are some exceptions (Fuchs 2010, Heinrich Böll Foundation 2003a, b, Ospina 2003, WSIS Civil Society Plenary 2003, 2005). The notion of the sustainable information society is today primarily a neoliberal ideological concept aimed at forestalling more fundamental changes and discussions that aim at a socio-economically just, ecologically preserving, culturally inclusive, and politically participatory information society. The dominant neoliberal ICT discourse ignores issues such as class and exploitation. Alternatives to this notion are marginalized and not sufficiently recognized in the public/scholarly debate. The project that remains to be realized is the critique and deconstruction of the dominant notion of sustainability and the connected dominant concept of the neoliberal information society. In our opinion, the primary focus should be on deconstruction by confronting the ideological promises with hard facts about the global problems that capitalism has produced and that, given the current framework, are likely to persist. The global capitalist crisis has resulted in cracks, fissures, and holes in neoliberalism. Movements such as the Arab Spring, the protests in countries like Greece, Spain, Portugal, or the Occupy Movement reveal demands for a more just and democratic society and the end of neoliberalism and the dominance of society by a powerful class. At the same time, we are witnessing an intensification of neoliberalism (hyper-neoliberalism) in official policymaking. The question of what kind of information societies we will have in the future depends on what the results of the struggle for alternatives to neoliberalism will look like. There is a potential to establish alternatives to neoliberalism and neoliberal information societies, but today these potentials are subordinated to a strong renewal and intensification of neoliberalism.

\section{References}

Archer, M.S. (2007) Social integration, system integration and global governance. In Frontiers of Globalization Research, ed. I. Rossi, 221-241, Berlin: Springer.

Bhaskar, R. (1993) Dialectic: The pulse of freedom. London: Verso.

Bradley, G. (2006) Social and community informatics. London and New York: Routledge.

Calhoun, C. and G. Derlugian (eds.) (2011a.) Aftermath. A new global economic order. New York: NYU Press.

Calhoun, C. and G. Derlugian (eds.) (2011b.) Business as usual. The roots of the global financial crisis. New York: NYU Press.

Calhoun, C. and G. Derlugian (eds.) (2011c.) The deepening crisis. Governance challenges after neoliberalism. New York: NYU Press.

Eagleton, T. (1991) Ideology: An introduction. London: Verso.

European Commission 2010. Europe 2020 - A strategy for smart, sustainable and inclusive growth. Communication from the commission. Retrieved from:

http://europa.eu/press_room/pdf/complet_en_barroso__007_-_europe_2020_-_en_version.pdf

Eurostat (2011) Information society statistics - Benchmarking Digital Europe: $\overline{20} \overline{1} 1-\overline{2} 015$ indicators. Retrieved from: http://epp.eurostat.ec.europa.eu/portal/page/portal/information_society/data/database

Forge, S. \& C. Blackman, E. Bohlin, M. Cave (2009) A Green Knowledge Society: An ICT policy agenda to 2015 for Europe's future knowledge society. A study for the Ministry of Enterprise, Energy and Communications, Government Offices of Sweden. Retrieved from: http://ec.europa.eu/information_society/ eeurope/i2010/docs/i2010_high_level_group/green_knowledge_society.pdf

Fuchs, C. (2008) Internet and society: Social theory in the information age. London and New York: Routledge.

Fuchs, C. (2010) Theoretical foundations of defining the participatory, co-operative, sustainable information society. Information, Communication, and Society 13(1): 23-47.

Fuchs, C. (2014) Digital labour and Karl Marx. New York: Routledge.

Gomez-Barroso, J.L. \& C. Feijoo, E. Karnitis (2008) The European policy for the development of an information society: The right path? JCMS: Journal of Common Market Studies 46(4): 787-825.

Hall, P. \& K. Löfgren (2004) The rise and decline of a visionary policy: Swedish ICT-policy in retrospect. Information Polity 9(3-4): 149-165. 
Harvey, D. (2005a.) A Brief History of Neoliberalism. Oxford: Oxford University Press.

Harvey, D. (2005b.) Spaces of neoliberalization: Towards a theory of uneven geographical development. Heidelberg: Franz Steiner Verlag.

Hatt, A-K. (2010) A digital agenda for Sweden. Speech at the Internetdagarna conference. Retrieved from: http://www.sweden.gov.se/sb/d/3211/a/155465

Heinrich Böll Foundation (2003a.) Charter of Civil Rights for a Sustainable Knowledge Society. Version 2.0. May 2003. Retrieved from: http://www.worldsummit2003.de/en/web/375.htm

Heinrich Böll Foundation (2003b.) Towards A Charter of Human Rights for Sustainable Knowledge Societies.

Henten, A. \& T.M. Kristensen (2000) Information society visions in the Nordic countries. Telematics and Informatics 17(1-2): 77-103.

Hilty, L. (2000) Towards a Sustainable Information Society. Informatique, August 2000, 2-9.

Hofkirchner, W. (2002) Projekt Eine Welt. Münster: LIT.

Hofkirchner, W. (2013) Emergent information: A unified theory of information framework. Singapore: World Scientific.

Horkheimer, M. \& T.W. Adorno (1944/2002) Dialectic of enlightenment. New York: Seabury.

Jessop, B. (2002) The future of the capitalist state. Cambridge: Polity Press.

Jessop, B. (2008) State power. A strategic-relational approach. Cambridge: Polity Press.

Jupp, V. (2006) Documents and critical research. In Data collection and analysis (Second edition) ed. R. Sapsford and V. Jupp, 272-290/ London: Sage.

Kant, I. (1998) Groundwork of the Metaphysics of Morals. New York: Cambridge University Press.

Lukács, G. (1923/1972) History and class consciousness. Cambridge, MA: MIT Press.

Macpherson, C.B. (1973) Democratic theory. Oxford: Oxford University Press.

Marx, K. (1867) Capital: Volume I. London: Penguin.

Marx, K. (1844/1975). Contribution to the critique of Hegel's philosophy of law: Introduction. In Karl Marx and Frederick Engels: Collected Works, Vol. 3 (1843-1844), 175-187. London: Lawrence \& Wishart.

Olsson, T. (2006) Appropriating civic information and communication technology: A critical study of Swedish ICT policy visions. New Media \& Society 8(4): 611-627.

Olsson, T., H. Sandström \& P. Dahlgren (2003) An information society for everyone? Gazette 65(4-5): 347-363.

Ospina, G.L. (2003) Planetary Sustainability in the Age of the Information and Knowledge Society. For a Sustainable World and Future. Working Toward 2015. Paris: UNESCO.

Stiglitz, J.E. (2003) Globalization and its Discontents. New York: Norton.

Swedish Government (2000) The Government Bill 1999/2000: 86 (An Information Society For All). Ministry of Industry, Employment and Communications, Sweden. Retrieved from: http://www.epractice.eu/files/ media/media_410.pdf

Swedish Government (2011) ICT for Everyone. A Digital Agenda for Sweden. Government Offices of Sweden. Retrieved from: http://www.sweden.gov.se/sb/d/2025/a/181914

van Dijk, T.A. (2011) Introduction: The study of discourse. In Discourse studies: A multidisciplinary introduction, ed. T.A. van Dijk. London: Sage.

Wodak, R. \& Meyer, M. (2009) Critical discourse analysis: History, agenda, theory and methodology. In Methods of critical discourse analysis, ed. R. Wodak \& M. Meyer, 1-33. London: Sage.

World Summit on the Information Society (WSIS) Civil Society Plenary (2003) Civil society declaration to the World Summit on the Information Society: Shaping information societies for human needs. Retrieved from: http://www.worldsummit2005.de/download_en/WSIS-CS-Dec-25-Feb-04-en.pdf

World Summit on the Information Society (WSIS) Civil Society Plenary (2005) Much more could have been achieved: Civil society statement on WSIS. Retrieved from: http://www.worldsummit2005.de/download_en/WSIS-CS-summit-statement-rev1-23-12-2005-en.pdf

Žižek, S. (eds.) (1994) Mapping ideology. London: Verso.

PIETER VERDEGEM, Ph.D., Assistant Professor, Department of Communication Sciences, Ghent University, pieter.verdegem@ugent.be

CHRISTIAN FUCHS, Ph.D., 2010-2013: Chair Professor, Departments of Informatics and Media, Uppsala University; 2013-: Communication and Media Research Institute, University of Westminster; c.fuchs@westminster.ac.uk 